\title{
GRAMMATICAL ERRORS PERFORMED BY TOURIST GUIDES IN GORONTALO CITY
}

\author{
Muziatun \\ Department of English Language, Faculty of letters and culture, State University of Gorontalo, Indonesia \\ Email: muziatun@ung.ac.id \\ Ansar Tario Jusuf \\ Department of English Language, Faculty of letters and culture, State University of Gorontalo, Indonesia \\ Email: ansartario@gmail.com
}

APA Citation: Muziatun, M., \& Jusuf, A. T. (2020). Grammatical errors performed by tourist guides in Gorontalo city. Indonesian EFL Journal, 6(1), 73-80. doi: 10.25134/ieflj.v6i1.2640.

Received: 08-07-2019

Accepted: 11-09-2019

Published: 01-01-2020

\begin{abstract}
The goal of this research is to investigate grammatical errors in speaking performed by tour guides in Gorontalo city. As demanding English is a compulsory language for those who work in the tourism sector when they deal with foreign tourists. This study aims to uncover grammatical errors produced by Gorontalo tour guides. Afterwards, this research uses sequential mixed method that proposed by Creswell, which aims to investigate and discover the types of grammatical errors followed by modus data. Moreover, the data analysis of this study uses a guideline that proposed by Politzer and Ramirez who explained the types of grammatical errors in detail. This study reveals that the ability of 12 tour guides produce speaking in a grammatically low manner. It indicates that the number of grammatical errors is dominated by the verb phrase, noun phrase and transformation. Followed by third person present singular, simple past tense, and past participle. Overall, this research is expected to contribute to tour guides in Gorontalo city, especially what needs to be emphasized by tour guides in speaking grammatically.
\end{abstract}

Keywords: grammatical errors; tourist guide; Gorontalo.

\section{INTRODUCTION}

The study of grammatical errors had been conducted by many researchers around the world (Asif, Zhiyong, Ali, \& Nisar, 2019; Çerçi̇, Derman, \& Bardakçi, 2016; Maros, Hua, \& Salehuddin, 2017; Uysal \& Aydin, 2017). Çerçi, Derman, and BardakçI (2016) identified Turkish as foreign language learners' grammatical errors. They investigated grammatical, syntactic, spelling, punctuation, and word choice errors. It revealed that errors are limited to the linguistic and intralingual developmental errors. In line with Çerçi, Derman, and BardakçI (2016), Hemati (2012) also explored the benefits of the effect of teacher, peer, and self-editing on the improvement of grammatical accuracy in writing, using three groups of participants. The results confirmed that teacher's editing as best way to improve students' grammatical errors rather than peer-editing and self-editing.

Some of Chakas' (2012) results of the study confirmed that participants' SMS and IM paragraphs displayed linguistic and contextual textisms, and errors in varying degrees. In the context of grammatical errors, Kyung-Im, and Hyekyeng (2017) also discovered the gap between learners' grammatical awareness and their perception of major grammatical items of
EFL learners from two local universities in South Korea. The results confirmed that there was a significant difference in the scores of tense, article, and voice for grammatical awareness between the high-level and the lowlevel group. This study also strongly highlighted the importance of individualized curriculum design for the effectiveness of teaching as well as self-initiated studying especially in grammatical aspect.

In practice, what is the relationship between grammatical errors and tourism? The use of correct grammatical aspects will be helpful for better service of tourism (Cappelli, 2016; Manca, 2016; Qiong, 2016). Primarily, for improvement of communication services for tourists who come from many countries around Asia. The challenge of English communication appears in the progress of International issues, such as decision of English language as requirement of communication is agreed upon to be as international language in region scale of ASEAN (Kirkpatrick, 2011, 2012; Muziatun, 2017), United Nations, International Academic and Education, international organization, and other communities. The challenge requires that English as the tool of communication among 
others such as economy, trading, education, law, culture, health and tourism sector.

It means that international issues that relate to these sectors decide to use English as the requirement of international communication (Khramchenko, 2019). So, they have become the main focuses in this era of globalization world. In the same way, Lembong (2018) has argued that particularly tourism sector is the second international activity after commerce, because tourism involves a people around the world. Besides, Richards (2001) states that English is a compulsory language for those who work in tourism sector when they deal with foreign tourists.

Subsequently, Gorontalo is one of regions in Indonesia, which has potentials to attract tourist through its destinations and nice hospitality based on what tourists have thought so far. This data has been provided by Gorontalo tourism department in 2016 year. Furthermore, this can be seen from a number of tourists have been increased each year, based on the statistics data provided by Gorontalo government tourism office in 2016. Afterwards, it announced that a number of foreign tourists in 2011 were 56.261 people and currently has been increased to approximately 231.000 people. Regarding the number of foreign tourists, absolutely tour guides should master a good English language. It is because, the tour guides will speak English to foreign tourists as regard the language is upon to be agreed as the requirement of international language.

For these reasons, tour guides need to know what grammar actually is and how important grammar is in communicating English (Hahn, Jurafsky, \& Futrell, 2020).. It is because that the important grammar in communication is to make ideas clearly. As stated by Richard (1987) knowledge of grammar emphasizes our capability to comprehend and generate language.

Additionally, David Crystal (2004) states grammar helps us to detect ambiguity in a language. It means that grammatical competence conveys all the ideas wanted to be covered by the speaker. Therefore, the listener will understand and get the meaning of the target language used by speaker without feeling ambiguity in a language. Moreover, grammar helps people to develop communication through referring the ideas using a correct form. When an idea is conveyed with the correct grammar, the idea will be easier to be understood by the listener. In a nutshell, tour guides should have realized that the important grammar in communication is to make ideas clearly.

Based on the decision letter of the Indonesian ministry of tourism, number: KM.82/PW.102/ MPPT-88 (1988) states that tourist guide is someone who in charge of giving guidance, instructions, and lighting related tourism destination in particular area. Besides that, tour guide also helps to everything needed by tourists such as giving explanation, services and accommodations. In the same way Suwantoro (1997) states that tour guide is someone who gives explanation and provides instructions for tourists related to the whole aspects which needed be seen by tourists, during their visit to tourism destinations, or certain tourist areas.

Regarding two opinions before, researchers conclude that tour guide is a profession that must be responsible to explain and to provide services related to tourists when they visit certain tourism destinations. In order to provide the services excellently to tourists, so tour guide should communicate clearly when conveying services to tourists. For instance, tour guide explains instruction of tourism destination to tourists by using clear language. Therefore, tourists can understand what have tour guide explained because of the excellent of communication skills.

According to Richard and Renandya (2002), speaking is an essential thing in communication. This means that speaking plays crucial things in communication. It is supported by Huebner (1969) who states that speaking is the main skill in communication. While, Byrne (1984) states that speaking is oral communication which involves productive and receptive skills of understanding between speaker and listener.

As stated by Cameron (2001) speaking is actively using a language to convey meanings orally. Furthermore, Brown (2004) states: speaking is a productive skill which can be directly and obviously observed. It means that, the listeners can recognize directly through observing what the speaker have said to the listeners, whether they understand or not.

Based on these ideas before, speaking is a direct communication that is happening between communicator and receiver (Khaparde, 2020). While the communicator speaks, at the same time, the receiver also hears. In this case, the speaker and listener should be able to 
understand each other; in order the idea of communication is achieved clearly.

There are some aspects in speaking (Dippold, Bridges, Eccles, \& Mullen, 2019; Tavakoli, Nakatsuhara, \& Hunter, 2020). Grammar is one of the aspects that should be concerned. It is needed in order to make the idea of speaking clearly. Hence, speaker should have realized the important of using grammar. As stated by Richard (1987) grammar comprehension emphasizes someone's capability to comprehend and generated language sentences

It means that grammatical competence conveys all the regulation wanted to be covered by the speaker. Therefore, the listener will understand and get the meaning of the target language used by the speaker. Furthermore, speaking cannot be separated tourism activities (Erazo, Ramírez, Encalada, Holguin, \& Zou, 2019), to fulfill the responsibility the tour guide complies the procedural of decision letters namely giving explanation and communication clearly to tourists as discussion in section before. It means that, in the tourism sector, the tour guide as the speaker and foreign tourists as listeners. Indeed, tour guide should speak clearly, in order tourist does not misunderstand.

According to Morris (1979) the definition of errors as general is the action, statement, or certainty that accidentally deviates of what is correct. In addition, he also states that error is the situation of false or incorrect knowledge, the act of deviation from code ethics, transgression and wrong doing. Subsequently in linguistic field, Corder (1973) states that error is branch of code which made by a person because of he or she has lack of knowledge concerning of the information rules of the language. Moreover, Ellis (1995) error in language is the incorrect deviation of someone who does not master the rules of the target language (Ellis, 1995).

Moreover, Dulay, Burt, and Krashen (1982) suggest that there are four kinds of error taxonomy. One of them is Linguistic Category Classification: this type of taxonomy carries the specification of error in terms of linguistic categories. The researchers focused on grammatical error. Grammatical error is the error in combining words into larger unit, such as phrases, clauses, and sentences. It consists morphological and syntactical error.

Morphological error involves a failure to obey the norm in supplying any part of word classes such as noun, verb, adjective, adverb, and preposition. Subsequently, syntactical errors affect texts larger than word such as phrase, clause, sentence, and paragraphs (James, 1998).

Based on the background presented earlier, the guiding questions for this paper are: What are the types of grammatical errors produced by tourist guides in Gorontalo city? What is the dominant type of grammatical errors produced by tourist guides in Gorontalo city?

\section{METHOD}

This study has been conducted in several destinations of Gorontalo city where the tour guides and foreign tourist tour. The research participants were 10 tour guides selected based on purposive sampling which is a technique to determine the sample of research with some consideration to make the data will be more representative. So the researchers consider the tour guide only in Gorontalo city, and they have an official license as the tourist guides and legalized by Ministry of tourism.

This study used documentation as the technique of collecting the data. So, the documentation in this study is the result of the voice recording of tour guides. While the tourist guides were guiding their tourists, the researchers observed and recorded their speaking. After recording, there was audio transcription process that would be made by researchers in order to analyze the data. The process of audio transcription here was the researchers wrote all of the words and sentences that produced by tourist guides during their speaking to foreign tourists. Moreover, the duration of collecting the data during three months start from June to August 2019. As responding the first research questions, this study used a description and classification of grammatical error types by using Linguistic category classification that proposed by Politzer and Ramirez (as cited in Dulay et al., 1982, p. 146-148). This taxonomy was the only taxonomy which separating error based morphology and syntax. Both levels are considered as a grammatical level, they aim to reveal grammatical error types. Subsequently, in order the researchers could investigate the dominant of error as responding for the second research questions, so the researchers used formula to count all grammatical error types into dominant type adapted from Fraenkel et al.

(2012) stated as follows:

$P=1 \Sigma \times 100 \%$ 


\section{RESULTS AND DISCUSSION}

The data of this research was gathered from tourist guides' speaking and their recording have been transformed into transcript form. All of the grammatical errors were investigated from transcript form and have been analyzed by using Linguistic Category Classification that proposed by Politzer and Ramirez (as cited in Dulay et al., 1982). The results are presented as follows:

Table 1 . The result of types of errors

\begin{tabular}{llcc}
\hline No & Types of errors & Frequency & Percentage \\
1. & Agreement of subject and verb & 14 & $38.88 \%$ \\
2. & Noun Phrase & 9 & $25.0 \%$ \\
3. & Transformations & 5 & $13.88 \%$ \\
4. & Third person singular present & 4 & $11.1 \%$ \\
5. & Simple past tense incorrect & 3 & $8.30 \%$ \\
6. & Past participle incorrect & 1 & $2.77 \%$ \\
& Total & 36 & $100 \%$ \\
\hline
\end{tabular}

Agreement of subject and verb

Substituent of verbs in verb phrase occurs because of someone produces replacement inappropriate auxiliary verbs in phrase or sentences. According to Verspoor and Sauter (2002) who stated that speaker or writer who used an appropriate auxiliary verb can express the differences of the event or situation. It means that, a speaker who produces the use of auxiliary verb appropriately, so that the listener can recognize the ideas clearly about the situation what the subject is, and also the listener can recognize indication of time whether it occurred at past, future or progressive. But in this case the researchers investigated that some participants

produced inappropriate auxiliary verb. Subsequently, this one of the data that has been identified as the inappropriate auxiliary verbs:

\section{They is serving many tourists there}

Concerning the idea of the sentence presented earlier, it occurred at progressive. It is because the sentence has been identified by the adverb of time "now" at the last sentence. Afterwards, the subject of sentence above "they" followed by the auxiliary verb "is". While the sentence contains the subject "they", means that the subject must be followed by the appropriate auxiliary verb "are". It is because the auxiliary verb "are" elucidates those subjects such as "they" as the third plural and "we" as the first person plural (Kent, 2015). As a result, the sentence must be corrected:

They are serving many tourists there

\section{Noun phrase errors}

In this study, the researchers investigated only three types of noun phrase errors that produced by participants, they are: error in number of using singular and plural, error in the use of preposition, and misordering of noun phrase.

1. Error in number of using singular/plural.

The researchers analyzed error in number of using singular/plural to be discussed into several categories. There were three errors in irregular plural incorrect. Additionally it followed by two omission of mark-s in regular plural nouns. The discussion of error in number of using singular/plural starts discussing irregular plural incorrect as follows:

\section{Irregular plural incorrect.}

As cited by Grammar Dictionary (2019) in English language, plural noun should be marked by adding " $s$ " or "es" at the end of a word. However, some certain nouns are plurals that should not be marked by adding "s" or "es" at the end of a word, which is irregular plural. In this case, the researchers analyzed that there were two occurrences of irregular plural incorrect produced by some participants. This one of the data of noun phrase error that has been analyzed as the irregular plural incorrect:

\section{Many childs}

Concerning the data presented earlier, this phrase consisted the words "many" as the adjective and "childs" as the "noun". So, the noun "child" as the head of phrase to be modified by adjective "many" It means that, the idea of phrase about the noun "childs" is plural. It is because the noun as the head of phrase to be described by the word "many" as the 
adjective. In this case, the participant 2 of this study produced plural noun "childs" that followed by adding "s" at the word of "childs". However, the phrase presented earlier was error; because English-Zone (2019) shows the word "child" as an irregular plural noun must not be added by adding " $s$ " at the end of the word. As a result the phrase must be corrected as follows:

\section{Many Childs Children}

Omission of mark-s in regular plural nouns.

Omission of mark-s in plural nouns is part of noun phrase error that consists adjective or determiner followed by inappropriate regular plural noun without mark-s at the end of a word. It should be the regular plural to be marked by adding "s" or "es" at the end of a word. Here is one of the representation data to be discussed as follows:

\section{Many flower}

The phrase above consists of two words between adjective "many" and noun "flower". In addition, the idea of the phrase about the noun "flower" is plural. It is because the noun as the head of phrase to be described by the word "many" as the adjective. In this case, the participant 12 of this study has recalled plural noun "flower" by deleting mark-s at the end of word "flower". Concerning that, the phrase presented earlier was error; this is because the word "flower" categorized as regular plural, so that the noun "flower" should be marked by adding "s" at the end of the noun "flower". As result the phrase must be corrected as follows: Many flowers

Regarding the description of data findings: Omission of mark-s in regular plural nouns before, so the researcher has corrected the overall data of Omission of mark-s in regular plural nouns by adding " $\mathrm{s}$ " at the end of the plural nouns:

\section{Error in the use of preposition.}

Error in the use of preposition is part of noun phrase error which consist the inappropriate preposition followed by noun phrase in the group of words. Here is the data to be discussed as follows:

The coffee in the table

As stated by Kent (2015) an appropriate preposition that can be used for indentifying a thing, which is being from the surface of an object is "on". Therefore, the use of preposition for identifying the object "the table" must be connected by preposition "on" it is because, indeed the subject "the coffee" is being from the surface of "the table" As result the sentence must be corrected as follows

The coffee in on the table

\section{Misordering of noun phrase}

Misordering of noun phrase occurs where the structure of noun phrase is broken. It is because; the placements of the head of modifier noun phrases are not arranged well. Here is one of the

representation data of misordering of noun phrase to be discussed as follows:

The view beautiful

The researchers investigated that there were three word classes on the phrase above; they are determiner "the", followed by noun "view" and closed by adjective "beautiful"

Concerning the data above, in order to be non misordering of noun phrase, so that the phrase to be started by determiner "the" followed by adjective "beautiful" and closed by the noun "view". As result, in order the misordering of noun phrase to be arranged the structure of noun phrase appropriately; here it is the phrase structure:

The view beautiful

\section{Transformation error}

In this study, the researchers only found two types of transformation error produced by Gorontalo tour guides recalled by foreign tourists, they are: question transformation and there transformation. The first discussion would be followed by question transformation.

\section{Question transformation}

Question transformation occurs to interrogative sentence that deviates of using assertive sentence or affirmative sentence, whether the sentence starts the word of present tense ("do" and "does) or the sentence starts the word of primary auxiliary verbs ("am", "is" and "are").

\section{Are you need transportations?}

Pertaining to the identification of representative data of question transformation, there were four word classes that produced by participants, they are primary auxiliary "are" subject "you", main verb "need" and the noun as the object "transportations".

As stated by Wilson (2013) the interrogative sentence which is started by marking primary auxiliary such as "am, is and are" should be followed by a subject and then followed by 
adjective. However, in this study, the participant produced that the subject "you" followed by the main verb "need", while the question mark is "are". It means that what the participant produced about the use of primary auxiliary in making interrogative sentence followed by main verb is wrong form, so that the question should be marked by marking "do" at the beginning of interrogative sentence. It is supported by Wilson (2013) who states the interrogative sentence which is started by marking "do" or "does" should be followed by a subject and then

followed by main verb. As a result, the data of question transformation should be:

\section{Are Do need transportions?}

Regarding the overall descriptions about question transformation, so the researchers corrected all data about question transformations.

\section{There transformation}

Wilson (2013) elucidate there transformation error is about there is and there are. For instance, error in there transformation such as there is occurred because it followed by inappropriate noun phrase which is identified as plural noun phrase. Furthermore, Wilson (2019) states the use of there in English is always confused by mostly people. It is because, they confuse to distinguish between the use of there $i$ and there are. However, in this study the researcher only found the errors of using there is.

Here is one of the data findings of there transformation to be discussed as follows:

There is many peanuts

As cited from British council site that accessed by researchers in 2019. It published that the use of there with part of be in English should be followed by appropriate noun phrase. It means that, the use of there is should be followed by singular noun phrase and there are should be followed by plural noun phrase. Regarding that, this contrary to what participant produced "there is" followed by plural noun phrase "many peanuts". It is because, the use of there is should be followed by singular noun phrase, but in fact the participant produced "there is" followed by plural noun phrase. As a result the data must be corrected as follows:

There is are many peanuts

\section{Third person singular incorrect}

The researchers investigated there four occurrences of third person singular incorrect recalled by some participants.

He always go there

Concerning the data above, it occurred at simple present tense. It is because; the idea of data is indicated by the word of habitual activity "always" after the subject "he". However, there is an incorrect verb produced by participants. It is because, while the subject "he" is third person singular, but in this case the participant produced only verb "go" without adding "s" at the end of verb. As stated by Wilson (2013) the use of verb in simple present tense of third person singular (she, he and it) should be marked by adding "s" at the end of verb. Furthermore the simple present tense is identified by doing a habitual

activity and stating a fact of something. As a result the verb must be corrected as follows:

He always go goes there

\section{Simple past tense incorrect}

Wilson (2013) states simple past tense incorrect is used to express an event that occurred in the past, indeed the event has ended and not related presently. He elucidates simple past tense incorrect is divided some categories, they are error in regular past tense verb and error in irregular past tense verb. In this case, the researcher only found error in irregular past tense.

\section{I eat the cake yesterday}

Concerning the data above, it occurred at simple past tense. It is because; the idea of data is indicated by the time signal "yesterday" at the end of sentence. However, there is a simple past tense incorrect produced by participant. It is because, while the event of sentence occurred in past tense, but in this case the participant produced only infinitive (present tense) "eat" without changing the infinitive in verb two (past tense) "ate". As stated by Wilson (2013) in arranging the simple sentence, the formula as follow

Subject + Verb 2 Past tense (regular/irregular verb past tense) + Time signal

In this case the infinitive "eat" from the data is categorized as the irregular verb. It means that, the infinitive would be changed the formation to be irregular past tense verbs should be changed as well as English standard. Irregular verbs do not follow the normal verb 
such a regular verb only to be added "ed" in the end of regular verb. Considering the explanation above, as a result the data must be corrected as follows:

I eat the cake yesterday

\section{Past participle incorrect}

Past participle contains a verb 3 which is formed from a regular verb or irregular verb. For regular verb (inivinitive) to be past participle can be added by adding suffix such as -ed, -d, -t, -n or - en. In addition, for irregular verb to be past participle verb is indefinitely to explain. It is because, the irregular verb to be past participle has own their arranged as well as spelled by English. In this study, the researcher only found one past participle incorrect recalled by participant. Here is the data.

I have eat

Kent (2015) states the arrangement of past participle to function as a verb namely the subject should be followed by have/has and verb 3 However, this is contrary what produced by participants, the past participle "I have eat". This is because "eat" is an infinitive verb, not participle verb, so that the infinitive "eat" should be the past participle verb "eaten" by adding suffix "en" at the end of infinitive "eat". Regarding that the suggested correction as follows:

$\underline{\text { I have eat eaten }}$

\section{CONCLUSSION}

This study does not represent the grammatical errors produced by all the tourist guides in Gorontalo, it only represents the grammatical error produced by only 10 tour guides. It revealed only 6 types of grammatical errors produced by tourist guides were subject-verb agreement, noun phrases, transformations, third person present singular incorrect, simple past tense incorrect and past participle incorrect.

The researchers conducted the analysis of this study, in which the largest number of grammatical errors produced by participants are dominated by agreement of subject and verb as many $38.88 \%$ percentage. It means that, the 10 tourist guides difficult to construct how the way to use the correct form of agreement of subject and verb. Moreover, the researchers would like to give some recommendations either in tour guides in Gorontalo city or English student.

This research is expected to be able to contribute and recommend to tour guides. It will be helpful by giving some information about what should be noted and emphasized by tour guide concerning the way conveying a speaking appropriates with the grammar aspect rules.

\section{REFERENCES}

Asif, M., Zhiyong, D., Ali, R. I., \& Nisar, M. (2019). Grammatical Errors Committed by Online Students: Case Study of Virtual University of Pakistan.

Azhar, B. S. (1999). Understanding and using English grammar. New York: Pearson Education.

Cappelli, G. (2016). English for Tourism: Using Translated Texts in the Classroom to Improve Writing Skills. Lingue e linguaggi, 17(1), 2138.

Çerçi, A., Derman, S., \& Bardakçi, M. (2016). An error analysis on TFL learners' writings. Gaziantep University Journal of Social Sciences, 15(2), 695-715. $\quad$ https://doi.org/ $10.21547 /$ jss. 256710

Chaka. (2015). Textisms, grammatical features and sentence types in the SMS and IM paragraphs of EFAL learners. Per Linguam: A Journal of Language Learning, 31(3), 65-85. DOI 10.5785/31-3-597.

Corder, S.P. (1973). Introducing applied linguistics. Lomdon: Pinguin Book Ltd. Great Britain.

Corder, S.P. (1978). Simple codes and the source of the second language learner's initial heuristic hypothesis. Studies in Second Language Acquisition,

Creswell. (2003). Research design: Qualitative, quantitative, and mixed methods approaches. London: Sage.

David, C. (2004). The importance of Grammar. Ontario, Canada: University of Ontario.

Decree of the general tourism number: KM.82/ PW.102/MPPT-88 (1988), concerning Tourism Guides and Regulators. Retrieved from SK Kementrian Pariwisata Indonesia tahun 1988.

Dippold, D., Bridges, S., Eccles, S., \& Mullen, E. (2019). Taking Elf Off the Shelf: Developing He Students' Speaking Skills through a Focus on English as a Lingua Franca. Linguistics and Education, 54, 100761.

Dulay, H. and Burt, M. and Krashen, S. (1982). Language Two. New York: Oxford University Press.

English Oxford Dictionary. (2018). Two definition of grammar. Retrieved from https://en.oxforddictionaries.com/word-of-the year/word-of-the-year-2018.

English-Zone. English irregular plural lists. Retrieved from http://www.english-zone.com/ grammar/

Erazo, M. A. C., Ramírez, S. I. M., Encalada, M. A. R., Holguin, J. V., \& Zou, J. H. (2019). 
English Language Skills Required by the Hospitality and Tourism Sector in El Oro, Ecuador. Theory and Practice in Language Studies, 9(2), 156-167.

Hahn, M., Jurafsky, D., \& Futrell, R. (2020). Universals of Word Order Reflect Optimization of Grammars for Efficient Communication. Proceedings of the National Academy of Sciences, 117(5), 2347-2353

Hemati, M. (2012). The effect of teacher, peer, and self-editing on improving grammatical accuracy in EFL learners' writing. Diversitate si Identitate Culturala in Europa, 9(2), 160168.

Jaya, I. K. P. A. Padmadewi, N. N. Saputra, I. N. P. H. (2013). An analysis of grammatical error in speaking committed by the tour guide in lovina singaraja. Jurnal Pendidikan Bahasa Inggris Undiksha, 1(1), 34-47.

James, C. (1998). Errors in Language and Use: Exploring Error Analysis. New York: Addison Wesley Longman.

Kementrian Pariwisata (1988). Keputusan Dirjen Pariwisata Nomor: KM.82/PW.102/MPPT-88 (1988), tentang Pramuwisata dan Pengatur Wisata. Jakarta: Kemenpar.

Kementrian Pariwisata. (2016). Jumlah wisatawan asing. Retrieved from http:// www.kemenpar.go.id/asp/ringkasan.asp?c=11

Kent. A. (2015). 10 in preparation \& practice exam TOEFL. Jakarta: Genta Group Production.

Khaparde, S. D. (2020). Development of Communication Skills: Stages, Barriers and Importance in the Present Era.

Khramchenko, D. S. (2019). Functional-Linguistic Parameters of English Professional Discourse. Professional Discourse \& Communication, 1(1), 9-20.

Kirkpatrick, A. (2012). English in Asean: Implications for Regional Multilingualism. Journal of Multilingual and Multicultural Development, 33(4), 331-344.

Kusumah, W (2011) Penelitian tindakan kelas. Jakarta: PT Indeks.

Kyung-Im, H. \& Hyekyeng, K. (2017). An investigation into the gap between Korean university students' grammatical awareness and perception. Indonesian Journal of Applied Linguistics, $\quad 7(1), \quad 117-126 \quad$ DOI 10.17509/ijal.v7i1.6864.

Lembong, T. (2018). Tom Lembong yakin FDI bisa selamatkan ekonomi Indonesia. Retrieved from http://www.warta ekonomi.co.id/read1 88496/tom-lembong-yakin-fdi-bisaselamatkan-ekonomi-indonesia.html
Manca, E. (2016). Official Tourist Websites and the Cultural Communication Grammar Model: Analysing Language, Visuals, and Cultural Features. Cultus, 9(1), 2-22.

Maros, M., Hua, T. K., \& Salehuddin, K. (2017). Interference in Learning English: Grammatical Errors in English Essay Writing among Rural Malay Secondary School Students in Malaysia. $e$-BANGI, 4(1).

Michael, S. (2005). Grammar: Oxford introductions to language study. New York: Oxford University Press.

Muziatun. (2017). Lexical Borrowing in Indonesian Printed Media. (Doctor of Philosophy), University of South Australia, Adelaide, South Australia.

Politzer, R. \& Ramirez, A. (1973). An error analysis of the spoken English of MexicanAmerican Pupils in a bilingual school and monolingual school. Language Learning.

Qiong, W. (2016). Errors and Solutions of Ce Translation on Tourism Spots Signs. CrossCultural Communication, 12(12), 14-19.

Richard, J. C., \& Renandya, W. A. (2001). Curriculum development in language teaching. Cambridge: Cambridge University Press.

Richard, J. C. \& Renandya, W.A. (1987). Methodology in Tesol, A book of readings. New York: Newbury House.

Richard, J. C and Renandya, W.A. (2002). Methodology in language teaching:An anthology of current practices. New York: Cambridge University Press.

Sugiyono. (2016). Statistika untuk penelitian. Bandung: Alfabeta.

Tavakoli, P., Nakatsuhara, F., \& Hunter, A. M. (2020). Aspects of fluency across assessed levels of speaking proficiency. The Modern Language Journal.

Uysal, N. D., \& Aydin, S. (2017). Foreign Language Teachers' Perceptions of Error Correction in Speaking Classes: A Qualitative Study. Qualitative Report, 22(1).

Verspoor \& Sauter. (2002). English sentence analysis: An introductory course: New York: John Benjamins Publishing.

Wilson, J. (2013). Essential English grammar: Jakarta: Mahirsindo Utama. 